\title{
Immunological characteristics of Spanish IDUs infected with HTLV-2 and HIV-1
}

\author{
Maria Abad*, Fernando Dronda, Ana Moreno, Maria J Perez-Elias, Ester Dominguez, Santiago Moreno, \\ Alejandro Vallejo*
}

From 15th International Conference on Human Retroviruses: HTLV and Related Viruses

Leuven and Gembloux, Belgium. 5-8 June 2011

\section{Background}

HTLV-2 infection has been detected in injecting drug users (IDUs) in Spain, who often are coinfected with HCV and HIV-1. It has been reported that HCV infection increases the immune activation of HIV-1-infected patients. Our objective was to analyze how HTLV-2 infection affects T-cell activation and other immunological parameters such as naïve and memory $\mathrm{T}$-cells and immunosenescence.

\section{Methods}

Eighteen HTLV-2 positive IDUs from Spain, also infected with HCV and HIV-1 were selected for this study. Fresh blood was immunostained with CD38 +/HLA-DR+ antibodies to define activated cells, CD45RA+/CD62L+ for naïve T-cells, CD45RA-/CD62Lfor effector memory T-cells and CD57+ for T-cell senescence, in both CD4+ and CD8+ cells. Immunological parameters were compared to two control groups, HCV-HIV-1 coinfected (N=7) and HIV-1 monoinfected patients $(\mathrm{N}=7)$.

\section{Results}

The median of CD4+ and CD8+ counts for the HTLV2-infected individuals were 497[312 632] and 784[5981206], respectively. CD4+ count was lower than control groups, with no statistical difference. Among CD4+ cells, naïve cells decreased while effector memory cells increased. No significant differences were found in CD8 + level and senescence when compared to group controls. CD8+ cell activation (8.5[2.93-12.21] was higher than control groups, either HCV-HIV-1-coinfected

\footnotetext{
* Correspondence: alejandro.vallejo@salud.madrid.org Department of Infectious Diseases, Hospital Ramon y Cajal, Madrid, 28035, Spain
}

patients (4.02 [3.54-6.11], $\mathrm{p}=0.038)$ or HIV-1-monoinfected patients (5.7[2.72-8.32], $\mathrm{p}=0.056)$.

\section{Conclusions}

HTLV-2 induces an increase of CD8 + cell activation and senescence in HCV-HIV-1 coinfected patients compared to HCV-HIV-1 or HIV-1 infection. Besides, the levels of $\mathrm{CD} 4+$ count and $\mathrm{CD} 4+$ naïve cells are lower in these patients. Nevertheless, the CD4+ effector memory cells increased. This might have beneficial effects on HIV-1 or HCV infection.

Published: 6 June 2011

doi:10.1186/1742-4690-8-S1-A96

Cite this article as: Abad et al.: Immunological characteristics of Spanish IDUs infected with HTLV-2 and HIV-1. Retrovirology 2011 8(Suppl 1):A96.

\author{
Submit your next manuscript to BioMed Central \\ and take full advantage of: \\ - Convenient online submission \\ - Thorough peer review \\ - No space constraints or color figure charges \\ - Immediate publication on acceptance \\ - Inclusion in PubMed, CAS, Scopus and Google Scholar \\ - Research which is freely available for redistribution \\ Submit your manuscript at \\ www.biomedcentral.com/submit
}

\section{Biomed Central}

